\title{
Eggshell as a calcium source replacing limestone meal in mink (Neovison vison) diets
}

\author{
Ø. Ahlstrøm ${ }^{1}$ and A. Skrede \\ Norwegian University of Life Sciences, Faculty of Biosciences, Department of Animal and Aquacultural Sciences \\ P.O. Box 5003, N-1432 Ås, Norway
}

KEY WORDS: Ca digestibility, P digestibility, growth, lactation, bone density, minks

Received: 7 September 2020

Revised: 3 November 2020

Accepted: 27 November 2020

${ }^{1}$ Corresponding author:

e-mail: oystein.ahlstrom@nmbu.no

\begin{abstract}
An experiment was carried out to study the suitability of ground eggshell as a calcium ( $\mathrm{Ca}$ ) source in mink (Neovison vison) diets replacing limestone meal. In the study two treatment groups of six multiparous lactating females were used. Animals were fed diets containing either eggshell or limestone from May 9 to weaning on June 15 (lactation period) and continued with 10 male kits from each respective group from June 16 until termination on November 28 (growing period). Moist diets containing mainly slaughterhouse by-products, fish, maize starch and soybean protein concentrate were used. The added eggshell or limestone represented about $60 \%$ of total $\mathrm{Ca}$ contents in the diets for lactating females and 27 (limestone diet) or 26\% (eggshell diet) in the kit growing period. Growth performance, $\mathrm{Ca}$ and $\mathrm{P}$ digestibility, and femur development were studied. The apparent total tract digestibility (ATTD) of $\mathrm{Ca}$ and $P$ of each diet was measured in six male kits. There were no significant differences between diets with added eggshell or limestone meal in ATTD of $\mathrm{Ca}$ and $\mathrm{P}$, but eggshell tended $(P<0.06)$ to promote higher $\mathrm{Ca}$ digestibility than limestone. Replacing limestone with eggshell in the diets for growing kits resulted in significantly $(P<0.05)$ higher feed intake and weight gain, increased body length, and lowered feed efficiency ratio. Dietary eggshell significantly $(P<0.05)$ increased length and weight of femur in mink kits, whereas femur thickness and contents of ash, $\mathrm{Ca}$ and $\mathrm{P}$ were unaffected. So, it can be concluded that eggshell can replace limestone as a suitable $\mathrm{Ca}$ source in mink diets.
\end{abstract}

\section{Introduction}

Dietary adequate intake of available $\mathrm{Ca}$ is essential for normal bone growth and development and many metabolic reactions. Recent literature on mineral requirements in mink is very limited, but the requirement for $\mathrm{Ca}$ and $\mathrm{P}$ in mink is estimated at $0.4 \%$ on a dry matter (DM) basis in the growing mink and $0.6 \%$ in lactating mink, assuming a $\mathrm{Ca}: \mathrm{P}$ ratio of 1:1-2:1 (NRC, 1982). In mink fed large amounts animal by-products with contents of bone, diets are likely to contain $\mathrm{Ca}$ levels above the requirements and to exhibit a favourable $\mathrm{Ca}: \mathrm{P}$ ratio. However, diets based on soft-tissue animal byproducts as fish, meat and organ tissues, and cereal grain sources, may contain abundant $\mathrm{P}$ but are likely to be deficient in $\mathrm{Ca}$. In addition, high levels of $\mathrm{P}$ and phytate in plant ingredients may inhibit $\mathrm{Ca}$ absorption (Denstadli et al., 2010). These diets must be balanced by a Ca source with low contents of $\mathrm{P}$ to ensure fulfilled dietary $\mathrm{Ca}$ requirement and adequate $\mathrm{Ca}: \mathrm{P}$ ratio.

Eggshell is a large natural source of $\mathrm{Ca}$ with a potential to cover dietary Ca requirements. Eggshell contains about $34 \% \mathrm{Ca}$, mainly as calcium carbonate $(94 \%)$, together with minor amounts of 
calcium phosphate, magnesium carbonate and organic substances (Murakami et al., 2007; Ray et al., 2017). Large amounts of eggshells are discarded as residues with an environmental impact challenge. Thus the required $\mathrm{Ca}$ to secure nutritional adequacy may be acquired from eggshell as a readily available low-cost alternative rather than using common commercial supplements (Kingori, 2011; Waheed et al., 2019). Furthermore, the use of eggshell as a dietary Ca source may contribute to reduce draining of limestone reserves, a non-renewable natural Ca resource (Oliveira et al., 2013).

Limestone meal is a common inorganic $\mathrm{Ca}$ supplement in animal diets. The aim of the present work was to study the effects of replacing limestone meal with ground chicken eggshell in moist mink diets on the apparent total tract digestibility (ATTD) of $\mathrm{Ca}$ and $\mathrm{P}$, growth performance, and physical measures and mineral content of femur bone. Moreover, nutrient digestibility in mink has been shown to correlate with digestibility in dogs and the mink model (Ahlstrøm and Skrede, 1998; Vhile et al., 2005; Tjernsbekk et al. 2014) and also may provide indications of $\mathrm{Ca}$ availability in canines.

\section{Material and methods}

\section{Ethical approval}

The study was in accordance with the institutional and national guidelines for the care and use of animals (Norwegian Ministry of Agriculture and Food, 1996, 2009). A specific permission to perform the study was not required since no sampling were done in live animals. The research farm laboratory has a general permission to carry out digestibility determinations in mink as the size of cages are identical to those approved for production animals.

\section{Animals, facilities and management}

The experiment was carried out on two treatment groups of six multiparous lactating females of black genotype fed diets containing either ground eggshell or limestone meal from May 9 to weaning on June 15 (lactation period) and continued with 10 male kits from each respective group until termination on November 28 (growing period, 164 days). The lactating females were chosen among animals that gave birth in the period of April 25-May 3. The females were distributed to each group to balance litter size (average 6.2), sex ratio (approximately $50 \%$ males and 50\% females) and birth date (average April 30). The females were kept in semi-outdoor houses in climbing cages (bottom cage: length
$77 \mathrm{~cm}$, width $39 \mathrm{~cm}$, height $46 \mathrm{~cm}$; top cage: length $66 \mathrm{~cm}$, width $39 \mathrm{~cm}$, height $46 \mathrm{~cm}$ ). The bottom cage was equipped with a nest box and both cages contained activity objects. Feed was provided two times a day in a bowl placed into the bottom cage. Leftovers were registered at every feeding. Daily feed intake was recorded for each litter, including female and pre-weaning kits. Females and kits were weighed after weaning of the kits on June 16 . The same day the females were euthanized with $\mathrm{CO}_{2}$ gas and both femurs were dissected and cleaned of soft tissues. The bones were boiled and dried before length and thickness were measured and ground preceding preparation for ash and mineral analyses.

In the follow up growth study with mink kits, groups were balanced according to body weight. The feeding procedure and housing conditions were the same as in the lactation period. Body weights were recorded every three weeks. At the end of the study the kits were euthanized with $\mathrm{CO}_{2}$ gas and both femurs were dissected, measured and analysed as for the females.

\section{Digestibility study}

Apparent digestibilities of $\mathrm{Ca}$ and $\mathrm{P}$ in the growth diets were determined a week after weaning (starting on June 24) with 7-8-week-old male kits, with an average body weight of $0.80 \mathrm{~kg}$. Six kits from each group were randomly chosen and kept in metabolic cages (length $77 \mathrm{~cm}$, width $39 \mathrm{~cm}$, height $46 \mathrm{~cm}$ ) designed for collection of faeces and separation of urine. The study lasted for seven days, starting with an adaptation period of three days followed by a four-day period of daily faecal collection. To the feed was added $0.2 \%$ yttrium oxide as an inert marker for calculating $\mathrm{Ca}$ and $\mathrm{P}$ digestibilities. Feed allowance was adjusted to cover the metabolizable energy requirement for maintenance and growth of $1140 \mathrm{~kJ} /$ day (Lassén et al., 2012).

\section{Diets}

The moist basal feeds contained mainly raw slaughterhouse by-products and fish together with maize starch and soyabean protein concentrate (Table 1). Ingredients with relatively low Ca content were chosen. The basal feeds were produced by a commercial feed plant (Vom og Hundemat AS, Trøgstad, Norway). The basal feeds were packed in portions of $1 \mathrm{~kg}$ and stored frozen at $-20{ }^{\circ} \mathrm{C}$ pending thawing at room temperature for about $16 \mathrm{~h}$ before fed.

Eggshell was provided as a finely ground powder from the production plant of Nortura at Revetal, Norway. The eggshell membrane was removed mechanically before grinding. The eggshell was 
Table 1. Formulation and analysed chemical composition of basal diets, calculated content of metabolizable energy (ME), and percent of ME derived from protein, fat and carbohydrate ( $P: F: C)$. Limestone and eggshell supplementation are given in Table 3

\begin{tabular}{|c|c|c|}
\hline Indices & $\begin{array}{l}\text { Lactation } \\
\text { period }\end{array}$ & $\begin{array}{l}\text { Growth } \\
\text { period }\end{array}$ \\
\hline \multicolumn{3}{|l|}{ Formulation, $\mathrm{g} / \mathrm{kg}$} \\
\hline cattle rumen & 250 & 250 \\
\hline swine lungs & 300 & 310 \\
\hline salmon scrap & 40 & - \\
\hline pangasius filet & 67 & 50 \\
\hline blood meal & 50 & 30 \\
\hline soybean protein concentrate & 30 & 30 \\
\hline maize starch & 80 & 120 \\
\hline soybean oil & - & 30 \\
\hline cellulose powder & 5 & 5 \\
\hline vitamin/mineral premix ${ }^{1}$ & 2 & 1 \\
\hline sodium phosphate & 10 & - \\
\hline water & 106 & 124 \\
\hline \multicolumn{3}{|l|}{ Chemical composition } \\
\hline dry matter (DM), g/kg & 37 & 35 \\
\hline ash, g/kg DM & 43 & 45 \\
\hline crude protein, g/kg DM & 435 & 439 \\
\hline crude fat, g/kg DM & 262 & 265 \\
\hline carbohydrates, g/kg DM & 260 & 245 \\
\hline \multicolumn{3}{|l|}{ Calculated ME } \\
\hline total ME content, MJ/kg DM & 20.0 & 19.9 \\
\hline ME distribution, $P: F: C, \%$ & $36: 46: 18$ & $37: 46: 17$ \\
\hline \multicolumn{3}{|c|}{$\begin{array}{l}{ }^{1} \text { contained per kg: IU: vit. A } 2000000 \text {, vit. } D_{3} 200000 \text {; mg: vit. E } \\
50000 \text {, vit } B_{1} 15000 \text {, vit. } B_{2} 3000 \text {, vit. } B_{6} 3000 \text {, vit } B_{12} 19.5 \text {, pantoth- } \\
\text { enic acid } 3 \text { 332, niacin } 5004 \text {, biotin } 30 \text {, folic acid } 300 \text {, Fe II sulphate } \\
610 \text {, Fe fumarate } 15280 \text {, Fe chelated } 4110 \text {, Cu II sulphate } 1250 \text {, Mn } \\
\text { oxide } 7502 \text {, Zn oxide } 9998 \text {, I (Ca-iodine) } 63.5 \text {, Se (Na selenite) 99.9, } \\
\text { Co (Co carbonate) } 60 \text {, carrier substance: Ca carbonate } 564 \mathrm{~g}\end{array}$} \\
\hline
\end{tabular}

ground to $<0.5 \mathrm{~mm}$ to ensure homogenous particle size. The limestone was a commercial product from Visnes Kalk AS (Lyngstad, Norway) with a particle size $<0.5 \mathrm{~mm}$. Analysed chemical composition of limestone and eggshell is shown in Table 2. Table 3 shows analysed contents of $\mathrm{Ca}$ and $\mathrm{P}$ in complete diets, and contribution of $\mathrm{Ca}$ from the experimental Ca sources.

Table 2. Chemical composition of limestone and eggshell, $\mathrm{g} / \mathrm{kg}$

\begin{tabular}{lll}
\hline Indices & Limestone & Eggshell \\
\hline Dry matter & 1000 & 994 \\
Ash & 1000 & 957 \\
Crude protein & nd & 31 \\
Calcium & 388 & 286 \\
Phosphorus & 0.05 & 0.73 \\
\hline
\end{tabular}

nd - not detected

\section{Chemical analyses}

Chemical analyses except for minerals were performed at the laboratory at Faculty of Biosciences, Norwegian University of Life Sciences.
Feeds, eggshell powder and limestone were analysed for DM (ISO 6496, 1999), ash (ISO 5984, 2002), and crude protein (CP) as Kjeldahl-N $\times 6.25$ (AOAC International, 2002; method 2001.11). Crude fat $(\mathrm{CF})$ was determined with petroleum ether and acetone extraction in an Accelerated Solvent Extractor (ASE 200) from Dionex (Sunnyvale, CA, USA). Carbohydrate was calculated by difference: carbohydrates $=\mathrm{DM}-(\mathrm{CP}+\mathrm{CF}+$ ash $)$.

For determination of minerals $(\mathrm{Ca}, \mathrm{P}, \mathrm{Mg}, \mathrm{K}$, Y), methods described in NS EN ISO 17294-2 were applied. For determination of Y, samples were digested with concentrated ultrapure $\mathrm{HNO}_{3}$ at $250{ }^{\circ} \mathrm{C}$ using a Milestone microwave UltraClave III (Milestone Srl, Sorisole, Italy). Samples were then diluted to $10 \% \mathrm{HNO}_{3}$ concentration. All elements were analysed by inductively coupled plasma optical mission spectrometry (ICP-OES analysis) with a Perkin Elmer Optima 5300 DV (PerkinElmer Inc., Shelton, CT, USA) at Eurofins Food and Feed Testing (Moss, Norway).

\section{Calculations and statistical analysis}

Apparent $\mathrm{Ca}$ and $\mathrm{P}$ digestibilities were determined by using the formula:

$[(\mathrm{Ca}$ or $\mathrm{P}$ concentration in diet $/ \mathrm{Y}$ concentration in diet $)$ - (Ca or $\mathrm{P}$ concentration in faeces/Y concentration in faeces)] / (Ca or P concentration in diet $/ Y$ concentration in diet).

Statistical analyses of data were performed with the SAS 9.3 computer software (SAS Institute Inc., Cary, NC, USA) applying the GLM procedure with the following model:

$$
\mathrm{Yij}=\mu+\alpha i+\varepsilon i j
$$

where: $\mu$-general mean, $\alpha \mathrm{i}$ - fixed effect of diet, $\varepsilon i j-$ random error component.

The results are presented as least-square means, and significant differences between means $(P<0.05)$. Measure of variance is presented as the standard error of the mean (SEM).

\section{Results \\ Chemical composition of diets}

A similar basal feed proximate composition, metabolizable energy (ME) content and distribution of ME between protein, fat and carbohydrate in the lactation and growing periods were noted (Table 1). The contents of $\mathrm{Ca}$ in the complete diets were about three times higher in the lactation period in comparison with the growth period. Within periods, levels of $\mathrm{Ca}$ and proportion of $\mathrm{Ca}$ from the supplemental $\mathrm{Ca}$ sources were similar for the limestone and eggshell groups (Table 3 ). 
Table 3. Analysed dietary $\mathrm{Ca}$ and $\mathrm{P}$ content and Ca:P ratio, and supplemental Ca from limestone and eggshell as $\mathrm{g} / \mathrm{kg}$ dry matter (DM) and as proportion of analysed dietary content

\begin{tabular}{|c|c|c|c|c|}
\hline \multirow{2}{*}{$\begin{array}{l}\text { Experimental } \\
\text { Ca source }\end{array}$} & \multicolumn{2}{|c|}{ Lactation period } & \multicolumn{2}{|c|}{ Growth period } \\
\hline & limestone & eggshell & limestone & eggshell \\
\hline Ca analysed, g/kg DM & 0.76 & 0.72 & 0.21 & 0.25 \\
\hline$P$ analysed, $g / k g D M$ & 0.49 & 0.33 & 0.26 & 0.26 \\
\hline Ca:P ratio & 1.55 & 2.18 & 0.80 & 0.96 \\
\hline $\begin{array}{l}\text { Supplemented Ca, } \\
\mathrm{g} / \mathrm{kg} \mathrm{DM}\end{array}$ & 0.513 & 0.449 & 0.077 & 0.065 \\
\hline $\begin{array}{l}\text { Proportion of dietary } \\
\text { Ca from supplemental } \\
\text { sources, \% }\end{array}$ & 67 & 63 & 27 & 26 \\
\hline
\end{tabular}

\section{Lactation period}

All females kept good body condition during the lactation period and there was no significant difference in body weight at weaning (Table 4). The body weight of kits at weaning was higher in the eggshell group than in the limestone group. The weight difference was significant in male kits $(P<0.02)$ and approached significance in female kits $(P<0.06)$. Physical measures and mineral content of female femurs revealed no significant differences between diets.

Table 4. Mean mink female and kit body weights at weaning, and weight, length, thickness and mineral content of female femur at weaning

\begin{tabular}{lccll}
\hline Indices & Limestone & Eggshell & SEM & $P$-value \\
\hline Body weight (BW), g & & & & \\
$\quad$ females & 1248 & 1186 & 68 & 0.54 \\
$\quad$ male kits & 586 & 650 & 18 & 0.02 \\
$\quad$ female kits & 521 & 562 & 15 & 0.06 \\
Femur, females & & & & \\
$\quad$ weight, g & 2.20 & 2.28 & 0.12 & 0.62 \\
length, mm & 46.9 & 48.3 & 0.81 & 0.26 \\
thickness, mm & 4.3 & 4.3 & 0.1 & 0.96 \\
weight, \% of BW & 0.18 & 0.19 & 0.01 & 0.30 \\
ash, g/kg dry matter & 621 & 628 & 0.47 & 0.39 \\
Ca, g/kg ash & 366 & 367 & 2.4 & 0.78 \\
P, g/kg ash & 193 & 192 & 1.6 & 0.67 \\
Mg, g/kg ash & 5.3 & 5.4 & 0.1 & 0.62 \\
K, g/kg ash & 1.1 & 1.3 & 0.1 & 0.50 \\
\hline
\end{tabular}

SEM - standard error of the mean

\section{Growing period}

Feed intake in June/July was higher in the limestone group than in the eggshell group, but the pattern changed, and the eggshell group had the highest feed intake from August to termination of the study (Figure 1). Total feed intake was slightly, but not significantly, higher in the eggshell group in comparison with the limestone group, whereas feed intake per unit body weight gain (FCR) was significantly $(P<0.004)$ lower in the eggshell group (Table 5). Body weights from June to August did not significantly differ between groups.

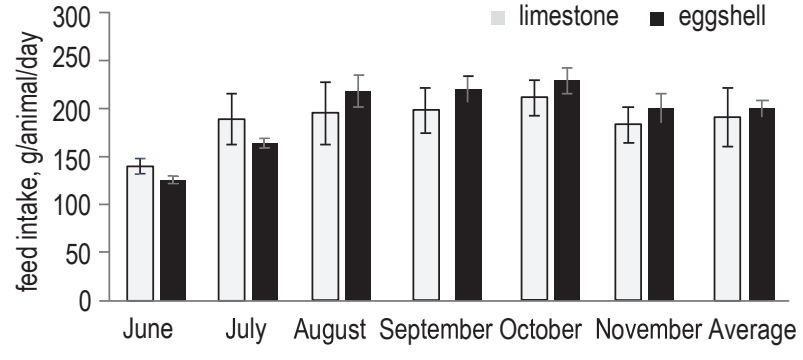

Figure 1. Mean intake of moist feed during the growth period from June 16 to November 28

All measures of body weights from September 19 to termination on November 28, final body length, and length of femur were significantly higher for the eggshell group than for the limestone group (Table 5). There were no differences in $\mathrm{Ca}, \mathrm{P}, \mathrm{Mg}$ and $\mathrm{K}$ concentrations in femur bone ash. However, since femur weight was slightly higher in animals fed eggshell, the retained mineral quantities were highest on the eggshell diet.

Table 5. Mean body weights, body weight gain, final body length, feed consumption, and weight, length, thickness and mineral content of femurs in mink kits

\begin{tabular}{lccll}
\hline Indices & Limestone & Eggshell & SEM & $P$-value \\
\hline Body weight (BW), g & & & & \\
$\quad$ June 24 & 824 & 815 & 17 & 0.72 \\
August 9 & 1688 & 1722 & 45 & 0.41 \\
September 19 & 2073 & 2336 & 68 & 0.01 \\
October 31 & 2295 & 2666 & 90 & 0.01 \\
$\quad$ November 28 & 2382 & 2772 & 96 & 0.01 \\
BW gain, g & 1558 & 1958 & 88 & 0.005 \\
Final body length, cm & 42.2 & 43.7 & 0.45 & 0.04 \\
Total feed intake & & & & \\
kg & 31.2 & 32.7 & 1.2 & 0.35 \\
FCR, g/g gain & 20 & 17 & 0.6 & 0.004 \\
Femur & & & & \\
weight, g & 3.48 & 3.77 & 0.13 & 0.13 \\
length, cm & 50.1 & 53.3 & 0.6 & 0.002 \\
thickness, mm & 4.73 & 4.82 & 0.09 & 0.51 \\
weight, $\%$ of BW & 0.15 & 0.14 & 0.004 & 0. \\
Ash, g/kg DM & 568 & 564 & 0.80 & 0.73 \\
Ca, g/kg ash & 372 & 372 & 0.95 & 0.99 \\
P, g/kg ash & 182 & 183 & 0.53 & 0.94 \\
Mg, g/kg ash & 6.2 & 6.5 & 0.2 & 0.25 \\
K, g/kg ash & 1.59 & 1.55 & 0.1 & 0.75 \\
\hline
\end{tabular}

FCR - feed convertion ratio, DM - dry matter, SEM - standard error of the mean

\section{Digestibility study}

The ATTD of $\mathrm{Ca}$ (Figure 2) showed a tendency towards higher values for the eggshell diet than for the limestone diet $(P<0.06)$. There was no difference between diets in the ATTD of P. The Ca from the supplemental sources only accounted for 


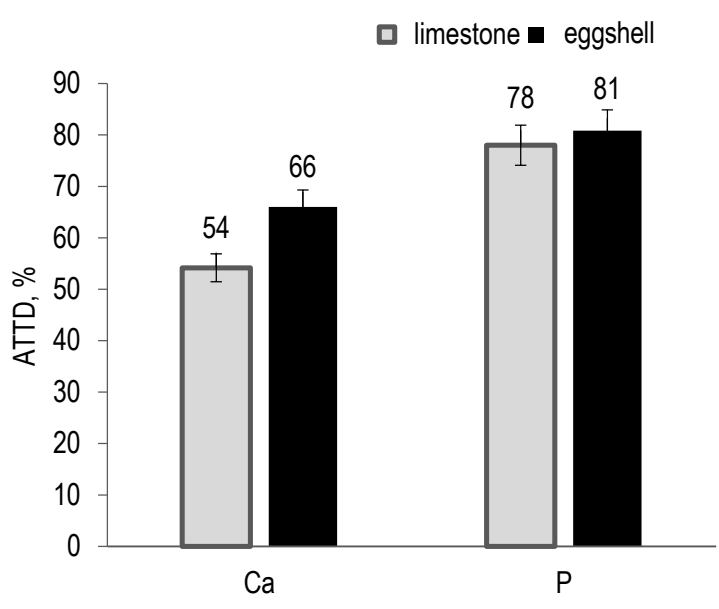

Figure 2. Apparent total tract digestibility (ATTD) of $\mathrm{Ca}$ and $\mathrm{P}$ in young male kits fed limestone or eggshell as supplemental $\mathrm{Ca}$ sources

27 (limestone) or 26\% (eggshell) of total dietary $\mathrm{Ca}$. Assuming similar digestibility of $\mathrm{Ca}$ from the basal ingredients in both diets, it was indicated that the digestibility of $\mathrm{Ca}$ from eggshells was higher than corresponding value for limestone.

\section{Discussion}

As a carnivorous species with short digestive tract, rapid passage and minor intestinal microbial activity, the differences in mineral utilization among different dietary sources may be greater in mink than in most other species. Chicken eggshell is widely available and can be converted to an animal feed supplement by low investment processes. Still, it is a relatively unknown $\mathrm{Ca}$ source in animal diets. Eggshell powder has shown, however, to be a good source of $\mathrm{Ca}$ for young growing pigs (Schaafsma and Beelen, 1999) and can replace calcium carbonate mined from non-renewable sources. An effective use of eggshell as a Ca source in mink diets depend on assessment of effects on digestibility and growth performance when fed to mink. To our knowledge, this study is the first to report the comparison of eggshell and limestone meal as $\mathrm{Ca}$ sources in mink diets.

The digestibility of $\mathrm{Ca}$ in different calcium sources is a crucial factor affecting $\mathrm{Ca}$ requirements. $\mathrm{Ca}$ is absorbed in the ionic state, i.e. $\mathrm{Ca} 2+$ ions (Bronner and Pansu, 1999), by active or passive absorption mainly from the small intestine. Gastric acids and enzymes promote the release of ionic $\mathrm{Ca}$. In dogs, active $\mathrm{Ca}$ absorption plays a dominant role in $\mathrm{Ca}$ deficient animals, whereas passive absorption is dominant during $\mathrm{Ca}$ excess (Tryfonidou et al., 2002). The eggshell and limestone meal used in our study had similar particle size, and particle size and solubility of $\mathrm{Ca}$ sources have minor influence on $\mathrm{Ca}$ absorbability in rats (Shahnazari et al., 2009), pigs (Ross et al., 1984; Merriman and Stein, 2016) and humans (Heaney et al., 1990).

As pointed out by Cargo-Froom et al. (2019), there is a scarce of knowledge on mineral digestibility in canines fed commonly used feed ingredients. The digestibility of $\mathrm{Ca}$ and $\mathrm{P}$ in mink fed different supplemental Ca sources has not been reported yet. Studies on pigs indicate similar digestibility of $\mathrm{Ca}$ in calcitic limestone and calcium carbonate, the main component of eggshell (Stein et al., 2011). In our study, the ATTD of $\mathrm{Ca}$ in diets with added ground eggshell tended to be higher than in diets with limestone meal. The high ATTD of both $\mathrm{Ca}$ and $\mathrm{P}$ was probably related to dietary contents below requirement and the high requirement for bone growth in rapidly growing young kits. The supplemental $\mathrm{Ca}$ from eggshell or limestone comprised less than $30 \%$ of the total Ca levels in the growing period. Thus, about $70 \%$ of total dietary Ca came from other sources, and higher ATTD of Ca in the eggshell diet than in the limestone diet can be explained by considerably higher digestibility of $\mathrm{Ca}$ from eggshell than from limestone. This may indicate easy ionization of eggshell $\mathrm{Ca}$ in the stomach. The diets used in our study had identical ingredient and nutrient composition except for the supplemental $\mathrm{Ca}$ sources, and the digestibility trials were carried out during a period of rapid growth and high $\mathrm{Ca}$ need for mineralization of the growing skeleton. Moreover, the kits had been fed their respective diets from weaning at six weeks of age and were thus well adapted to their diets prior to the digestibility trial.

The growing diets were formulated to contain suboptimal $\mathrm{Ca}$ levels to increase sensitivity to availability differences. According to Hazewinkel et al. (1991) and Hill et al. (2001) there is an inverse relationship between $\mathrm{Ca}$ content in the diet and $\mathrm{Ca}$ digestibility in dogs. Other studies with dogs have shown a lack of adaptation of $\mathrm{Ca}$ absorption when challenged with different $\mathrm{Ca}$ intake (Mack et al., 2015; Schmitt et al., 2018). However, the ATTD of $\mathrm{Ca}$ in dogs may decrease if Ca levels are below the requirement due to a greater proportion of endogenous losses (González-Vega et al., 2013). Increasing $\mathrm{Ca}$ levels may not influence the ATTD of $\mathrm{Ca}$ in pigs, but decrease P digestibility (Stein et al., 2011). In our study, the difference in total level of $\mathrm{Ca}$ in the diets was moderate and may not have influenced the comparison of $\mathrm{Ca}$ and $\mathrm{P}$ digestibility between diets. 
It is well known that dietary Ca deficiency can reduce bone formation and bone mineral density. In our study, dietary eggshell increased femur length of mink kits in comparison with limestone, while femur weight, thickness and contents of $\mathrm{Ca}$ and $\mathrm{P}$ were unaffected, indicating no disturbances of skeletal development. The increased femur length may not be indicative of differences in bone growth related to experimental $\mathrm{Ca}$ sources but was rather due to increased body size of animals fed eggshell.

In the present study it was shown that supplemental ground eggshell tended to improve feed intake, body weight gain and feed efficiency in comparison with limestone meal. However, both groups showed lower energy intake and body growth than recommended in practical farming in male mink kits (Lassén et al., 2012) during the last part of the study. The reason was probably the suboptimal dietary fat content. Commercial feeds normally have about $15 \%$ higher ME content and 55\% average ME from fat in the last part of the growing-furring period. Higher dietary fat content will give higher energy intake and body weights due to higher fat deposition. Typical final body weights in males is around $3600 \mathrm{~g}$ (Lassén et al., 2012). It is well known that Ca deficiencies has negative effects on body growth, but the data on bone parameters did not indicate the animals suffered from a deficiency. Furthermore, we are not aware of previous studies indicating effects of $\mathrm{Ca}$ sources on growth performance in mink. The differences in growth performance are thus difficult to explain, although the diets used in the growing period had suboptimal $\mathrm{Ca}$ contents in comparison with requirement figures (NRC, 1982). Conceivably, the high ATTD of $\mathrm{Ca}$ for the eggshell diet may have had a compensatory beneficial effect on animal performance. The ground eggshell used in our study contained $3.1 \% \mathrm{CP}$, indicating a considerable content of eggshell membranes. This minor amount would not be expected to influence dietary protein supply, but the membranes are known to contain bioactive compounds and are used in sports nutrition to increase performance of athletes (Kingori et al., 2011). Thus, the positive effects of chicken eggshell on growth performance in mink may deserve further studies.

\section{Conclusions}

Eggshells derived from egg processing are waste products with a potential as a natural source of calcium carbonate in animal diets. The obtained values of apparent $\mathrm{Ca}$ and $\mathrm{P}$ digestibility, bone density and growth performance in mink, have shown that egg- shell was a similar or better source of $\mathrm{Ca}$ than limestone meal. It can be concluded that eggshell may be preferred over limestone as a Ca source in mink diets. It is suggested that ground eggshell is a promising $\mathrm{Ca}$ source to support an adequate $\mathrm{Ca}$ intake in canines.

\section{Acknowledgement}

We acknowledge the technical staff at the research farm at the Norwegian University of Life Sciences for taking good care of the animals and skilful work during sampling.

\section{References}

Ahlstrøm Ø., Skrede A., 1998. Comparative nutrient digestibility in dogs, polar foxes, mink, and rats. J. Nutr. 128, 2676S-2677S, https://doi.org/10.1093/jn/128.12.2676S

AOAC International, 2002. Official methods of analysis of AOAC International. 17th Edition. Gaithersburg, MD (USA)

Bronner F., Pansu D., 1999. Nutritional aspects of calcium absorption. J. Nutr. 129, 9-12, https://doi.org/10.1093/jn/129.1.9

Cargo-Froom C.L., Fan M.Z., Pfeuti G., Pendlebury C., Shoveller A.K., 2019. Apparent and true digestibility of macro and micro nutrients in adult maintenance dog foods containing either a majority of animal or vegetable proteins. J. Anim. Sci. 97, 1010-1019, https://doi.org/10.1093/jas/skz001

Denstadli V., Romarheim A.T., Sørensen M., Ahlstrøm Ø., Skrede A., 2010. Effects of dietary phytic acid on digestibility of main nutrients and mineral absorption in mink (Mustela vison). J. Anim. Feed Sci. 19, 104-112, https://doi.org/10.22358/ jafs/66274/2010

González-Vega J.C., Walk C.L., Liu Y., Stein H.H., 2013. Determination of endogenous intestinal losses of calcium and true total tract digestibility of calcium in canola meal fed to growing pigs. J. Anim. Sci. 91, 4807-4816, https://doi.org/10.2527/jas.20136410

Hazewinkel H.A., Van Den Brom W.E., Van 'T Klooster A.T., Voorhout G., van Wees A., 1991. Calcium metabolism in Great Dane dogs fed diets with various calcium and phosphorus levels. J. Nutr. 121, suppl. 1, S99-S106, https://doi.org/10.1093/ jn/121.suppl_11.S99

Heaney R.P., Recker R.R., Weaver C.M., 1990. Absorbability of calcium sources: The limited role of solubility. Calcif. Tissue Int. 46, 300-304, https://doi.org/10.1007/BF02563819

Hill R.C., Burrows C.F., Ellison G.W., Bauer J.E., 2001. The effect of texturized vegetable protein from soy on nutrient digestibility compared to beef in cannulated dogs. J. Anim. Sci. 79, 2162-2171, https://doi.org/10.2527/2001.7982162x

ISO (International Organization for Standardization), 1999. Animal feeding stuffs - Determination of moisture and other volatile matter content, ISO 6496 (Geneva, Switzerland)

ISO, International Organization for Standardization, 2002. Animal feeding stuffs - Determination of crude ash, ISO 5984. Geneva (Switzerland)

Kingori A.M., 2011. A review of the uses of poultry eggshells and shell membranes. Int. J. Poultry Sci. 10, 908-912, https://doi. org/10.3923/ijps.2011.908.912 
Lassén T.M., Tauson A.-H., Ahlstrøm Ø., Rouvinen-Watt K., Sandbøl P., Koskinen N., Christiansen M.L.E., 2012. Energy and main nutrients in feed for mink and foxes. In: A. Skrede (Editor), Rep. No. 63, 2nd Edition, Nordic Association of Agricultural Scientists

Mack J.K., Alexander L.G., Morris P.J., Dobenecker B., Kienzle E., 2015. Demonstration of uniformity of calcium absorption in adult dogs. J. Anim. Phys. Anim. Nutr. 99, 801-809, https:// doi.org/10.1111/jpn.12294

Merriman L.A., Stein H.H., 2016. Particle size of calcium carbonate does not affect apparent and standardized total tract digestibility of calcium, retention of calcium, or growth performance of growing pigs. J. Anim. Sci. 94, 3844-3850, https://doi.org/10.2527/jas.2015-0252

Murakami F.S., Rodrigues P.O., de Campos C.M.T., Silva M.A.S., 2007. Physicochemical study of $\mathrm{CaCo} 3$ from egg shells. Ciénc. Tecnol. Aliment. Campinas 27, 658-662, https://doi.org/10.1590/S0101-20612007000300035

NRC (National Research Council), 1982. Nutrient Requirement of Mink and Foxes. National Academy Press. Washington, DC (USA)

Oliveira D.A., Benelli P., Amante E.R., 2013. A literature review on adding value to solid residues: egg shells. J. Clean. Prod. 46, 42-47, https://doi.org/10.1016/j.jclepro.2012.09.045

Ray S., Barman A.K., Roy P.K., Singh B.K., 2017. Chicken eggshell powder as dietary calcium source in chocolate cakes. Pharma Innov. J. 6, 01-04

Ross R.D., Cromwell G.L., Stahly T.S., 1984. Effects of source and particle size on the biological availability of calcium in calcium supplements for growing pigs. J. Anim. Sci. 59, 125-134, https://doi.org/10.2527/jas1984.591125x

Schaafsma A., Beelen G.M., 1999. Eggshell powder, a comparable or better source of calcium than purified calcium carbonate: piglet studies. J. Sci. Food Agric. 79, 1596-1600, https:// doi.org/10.1002/(SICI)1097-0010(199909)79:12<1596::AIDJSFA406 $>3.0 . C O ; 2-A$
Schmitt S., Mack J., Kienzle E., Alexander L.G., Morris P.J., Colyer A., Dobenecker B., 2018. Faecal calcium excretion does not decrease during long-term feeding of a low-calcium diet in adult dogs. J. Anim. Physiol. Anim. Nutr. 102, e798-e805, https://doi.org/10.1111/jpn.12837

Shahnazari M., Martin B.R., Legette L.L., Lachcik P.J., Welch J., Weaver C.M., 2009. Diet calcium level but not calcium supplemental particle size affects bone density and mechanical properties in overiectomized rats. J. Nutr. 139, 1308-1314, https://doi. org/10.3945/jn.108.101071

Stein H.H., Adeola O., Cromwell G.L., Kim S.W., Mahan D.C., Miller P.S., 2011. Concentration of dietary calcium supplied by calcium carbonate does not affect the apparent total tract digestibility of calcium but decreases digestibility of phosphorus by growing pigs. J. Anim. Sci. 89, 2139-2144, https://doi.org/10.2527/jas.2010-3522

Tjernsbekk M.T., Tauson A.-H., Ahlstrøm Ø., 2014. Ileal, colonic and total tract nutrient digestibility in dogs (Canis familiaris) compared with total tract digestibility in mink (Neovison vison). Arch. Anim. Nutr. 68, 245-261, https://doi.org/10.108 0/1745039X.2014.915137

Tryfonidou M.A., van den Broek J., van den Brom W.E., Hazewinkel H.A.W., 2002. Intestinal calcium absorption in growing dogs is influenced by calcium intake and age but not by growth rate. J. Nutr. 132, 3363-3368, https://doi.org/10.1093/jn/132.11.3363

Vhile S.G., Skrede A., Ahlstrøm Ø., Hove K., 2005. Comparative apparent total tract digestibility of major nutrients and amino acids in dogs (Canis familiaris), blue foxes (Alopex lagopus) and mink (Mustela vison). Anim. Sci. 81, 141-148, https://doi. org/10.1079/ASC42220141

Waheed M., Butt M.S., Shehzad A., Adzahan N.M., Shabbir M.A., Suleria H.A.R., Aadil R.M., 2019. Eggshell calcium: a cheap alternative to expensive supplements. Trends Food Sci. Technol. 91, 219-230, https://doi.org/10.1016/j.tifs.2019.07.021 